DOI: $10.1515 /$ lpts-2016-0017

\title{
THEORETICAL AND EXPERIMENTAL INVESTIGATIONS OF CYLINDRICAL AIR-HEATING SOLAR COLLECTOR
}

\author{
I. Pelece ${ }^{1}$, P. Shipkovs ${ }^{2}$ \\ ${ }^{1}$ Latvia University of Agriculture, 2 Liela Str., Jelgava, LV-3000, LATVIA \\ ${ }^{2}$ Institute of Physical Energetics, 21 Aizkraukles Str., Riga, LV-1006, LATVIA \\ shipkovs@edi.lv
}

\begin{abstract}
Solar energy is used not only at low latitudes, where it is available at large amounts, but also at higher latitudes, where height of sun and irradiance are significantly lower. On the other hand, the length of day at higher latitudes is longer in summer than at low latitudes, and also the path of the sun is longer.

The present research deals with seeking for new shapes of solar collectors capable of receiving more solar energy.

For designing and evaluating new shapes of solar collectors, it is necessary to have new methods for simple calculations of energy received from the sun by surface of any shape and direction. Such a method is explained in the present paper.

Based on calculations by the proposed method, a new form of solar collector - a cylindrical collector - has been worked out. This collector is intended for air heating, but main principles can also be used for water heating, and even for photovoltaics.

A cylindrical collector receives more energy in the morning and evening than a flat one, but at midday power of both collectors is equal, if effective areas are equal. Daily energy sum of the cylindrical solar collector is 1.5 times greater than that of the flat one.
\end{abstract}

Keywords: air heating, collector, cylindrical, solar energy.

\section{INTRODUCTION}

Along with other kinds of renewable energy, solar energy has been used not only at low latitudes, where it is available at large amounts, but also at higher latitudes, where height of the sun and, therefore, irradiance are significantly lower. On the other hand, the length of the day at higher latitudes is longer in summer than at low latitudes, and also the path of the sun is longer (for example, at the sixtieth degree of latitude during the summer solstice it is from $41^{0}$ to $319^{\circ}$, but the length of day is $17 \mathrm{~h} 51 \mathrm{~min}$ ). Therefore traditional solar devices used in southern countries are not appropriate in higher latitudes, and new kinds of solar collectors and other devices must be developed. 
In general, there are two ways to improve solar collectors. The first one is to seek for new better materials for the absorber and transparent cover for better use of the received energy. There are very many investigations in this direction (Kadirgan 2006; Siwulski et al. 2005; Hobbi \& Siddiqui 2009). But there is also another way to improve geometry of the collector to receive more energy. In this direction there is much less research mainly devoted to tracking systems and concentrators (Chong \& Wong 2009). Traditionally the positioning of the collector and the tilt angle are understood with the geometry of the collector, but actually also the shape of the absorber itself can be better than flat. There are only few works, for example, (Abdulhadi \& Ghorayeb 2006; Kurtbas \& Durmus 2007) dealing with new shapes of collectors. Traditional flat-plate solar collector is capable of receiving solar energy approximately from $160^{\circ}$ wide angle that corresponds to approximately 10 hours of work. Energy gain in the morning and evening is small. This problem can be solved by using the sun tracking flat-plate collector, but such mechanisms are expansive and moving parts need special maintenance and are not durable against wind. The present research deals with seeking for new shapes of solar collectors capable of receiving more solar energy during all day and from all sides.

Traditionally efficiency has been used for characterising a solar collector. Efficiency is defined as ratio between thermal power produced by the collector to that received by collector from the sun. But the efficiency really does not characterise energy gain from the collector. For calculation of the energy gain it is also necessary to know the amount of energy received by the collector that in some situations (especially when the collector is not flat) can be a rather complicated task. Efficiency characterises only materials and technologies used in construction of the collector, but not the geometry and positioning of it. For example, efficiency of a flat-plate solar collector will be the same when a collector is positioned horizontally or in the optimal slope, while energy gain can differ 1.4 times (Slama 2009). Hence, efficiency is not usable when we try to get more energy by changing shape and positioning of the collector, and new ways for characterising the solar collectors must be used. We suggest using coefficient of proportionality between the energy gain from a solar collector and the sum of global solar energy at the same period of time.

For designing and evaluating new shapes of solar collectors, it is also necessary to have new methods for simple calculation of energy received from the sun by surface of any shape and direction. Such method has been proposed in the present research.

Based on calculations by the offered method, a new form of solar collector a cylindrical collector - has been worked out. Such a collector has been made and measurements of energy production have been carried out. This collector is intended for heating air, but main principles can be used for water heating as well, and even for photovoltaics (PV). Cylindrical solar collector has several advantages in comparison with the traditional flat-plate one: it receives solar radiation from all sides during the day, even if the length of day is 17 hours; it does not contain moving parts; it is more durable against wind than a flat-plate collector. 


\section{MATERIALS AND METHODS}

\subsection{New Method for Calculating Received Energy}

\subsubsection{Coordinates of the Sun}

The first step to calculate energy received by some surface is calculation of coordinates at which the sun is seen in the sky. Height of the sun and azimuth are easy to use.

Coordinates of the sun can also be find at some Internet pages (for example, "http://ssd.jpl.nasa.gov/horizons.cgi," n.d.), but such a sheet is not convenient for use in further calculations, formulae are more appropriate.

Therefore, we obtained such formulae from astronomical considerations, using coordinate transformation formulae between several coordinate systems (Zagars $\&$ Vilks 2005). After few transformations we obtain sinus of the height of the sun:

$$
\sin \delta=(\cos s \cdot \cos \chi+\sin s \cdot \sin \chi \cdot \cos \varepsilon) \cdot \cos \varphi+\sin \chi \cdot \sin \varepsilon \cdot \sin \varphi,
$$

where $\delta$ is the height of the sun, $s$ is sidereal time, $\chi$ is ecliptic length of the sun, $\varepsilon$ is slope of the earth axis $\left(23^{\circ}\right)$ and $\varphi$ is latitude of the place. The sidereal time $s$ can be assumed with good accuracy as

$$
s=((N-81) \cdot 24 / 365.25+t+12+\lambda) \cdot \pi / 12,
$$

where $N$ denotes the day of the year counted from 1 January, $t$ is time within the day in hours, and $\lambda$ is longitude of the place.

The ecliptic length $\chi$ in the first approximation can be assumed as

$$
\chi=\frac{N-81}{365.25} \cdot 2 \pi \text {. }
$$

It means a full circle in year, but a year in astronomy starts at the spring point. Then, if we know $\sin \delta, \cos \delta$ can be obtained from simple geometrical formula

$$
\cos \delta=\sqrt{1-\sin ^{2} \delta} .
$$

The trigonometric functions of the azimuth $A$ of the sun can be calculated as follows:

$$
\begin{gathered}
\sin A=\frac{\sin s \cdot \cos \chi-\cos s \cdot \sin \chi \cdot \cos \varepsilon}{\sqrt{1-\sin ^{2} \delta}} \text { and } \\
\cos A=\frac{(\cos s \cdot \cos \chi+\sin s \cdot \sin \chi \cdot \cos \varepsilon) \cdot \sin \varphi-\sin \chi \cdot \sin \varepsilon \cdot \cos \varphi}{\sqrt{1-\sin ^{2} \delta}} .
\end{gathered}
$$

More detailed presentation of this method is given in (Pelece 2011). Later also other authors (Xiaoyan 2012) used a very similar method. 


\subsubsection{Energy Received by Surface}

Solar radiation received by some surface consists of the direct or beam radiation and the diffused one. In general, direct radiation received from the sun on horizontal flat surface can be written as

$$
R=R_{0} \cdot P^{m} \cdot \sin \delta,
$$

where $R_{0}$ is solar constant ( $1367 \pm 7 \mathrm{~W} / \mathrm{m}^{2}$, from "ISO 9488:1999(E/F) 3.24,"), $P$ is lucidity of the atmosphere, in our case taken as constant and equal to 0.78 (Pelece et al. 2010), but $\mathrm{m}$ is atmosphere mass - a quantity characterising thickness of the atmosphere, which solar rays pass through in relative units compared with when the sun is at the zenith. It has been found (Young 1994) that the mass of the atmosphere with good accuracy (error $2 \%$ percent at horizon, higher even less) can be expressed as

$$
m=\frac{1.002432 \cdot \cos ^{2} \theta+0.148386 \cdot \cos \theta+0.0096467}{\cos ^{2} \theta+0.149864 \cdot \cos \theta+0.0102963 \cdot \cos \theta+0.000303978}
$$

where $\Theta$ is zenith angle of the sun, i.e. distance of the sun from the zenith, therefore $\cos \theta=\sin \delta$.

If receiving surface is not horizontal and/or is not flat, the main formula is $I=I_{0} \cdot \cos \alpha$, where $I$ is the intensity of solar radiation received by surface, $I_{0}$ is that on surface perpendicular to sun rays and $\alpha$ is the incidence angle of solar rays on surface, i.e., angle between sun rays and surface normal. If we know the height of the sun $\delta$, azimuth of the sun $A$, slope of the surface (or surface element, if the surface is not flat) $\beta$ and azimuth of the surface normal $B$, then $\cos \alpha=\sin \delta \cdot \cos \beta+\cos \delta \cdot \sin \beta \cdot \cos (A-B)$. As we know $\sin A$ and $\cos A$, but not the azimuth $A$, we can use formula $\cos (A-B)=\cos A \cdot \cos B+\sin A \cdot \sin B$. Then we obtain

$$
I=I_{0} \cdot(\sin \delta \cdot \cos \beta+\cos \delta \cdot \sin \beta \cdot(\cos A \cdot \cos B+\sin A \cdot \sin B)),
$$

where $I_{0}=R_{0} \cdot P^{m}$. For calculation of energy received by some surface within some time, this value must be integrated by surface (in the case of flat surface it means multiplying by surface area) and by time. Integrating by time is rather complicated, because both height and azimuth of the sun depend on time, and so does air mass. Therefore, numerical integrating can be used.

The other part of the global solar radiation is the diffused one. As several authors, for example, (Chikh et al. 2012) denote, usually only global radiation has been measured and therefore the diffused one must be evaluated theoretically. From several works it follows that the diffused radiation can be in good approximation considered as constant: Mghouchi et al. (2014) found it is $50 \mathrm{~W} / \mathrm{m}^{2}$, Andersen et al. (2015) found it to be $120 \mathrm{~W} / \mathrm{m}^{2}$ and Ahwide et al. (2013) found that in summer the diffused radiation is $100 \mathrm{~W} / \mathrm{m}^{2}$. Therefore, we consider the diffused radiation to be constant and equal to $100 \mathrm{~W} / \mathrm{m}^{2}$. 


\subsubsection{Effective Area}

In some cases, especially if only the total received radiation, not its distribution, is required, calculations can be even more simplified using the effective area. The effective area of some surface, independently of its shape and orientation, is equivalent to the area of its projection on plane perpendicular to solar rays (or area, at which the receiving surface can be seen in direction of solar rays). Then radiation received by some surface is

$$
I=I_{0} \cdot S_{e f},
$$

where $I_{0}$ is the radiation on plane perpendicular to solar rays and can be calculated

$$
I_{0}=R_{0} \cdot P^{m}
$$

as explained in Section 2.1.2, and $S_{e f}$ is the effective area of the receiving surface.

For example, the effective area for a flat-plate collector is $S_{\mathrm{ef}}=\mathrm{S} \cdot \cos \alpha$, where $\alpha$ is the incidence angle of solar rays on surface, and solar radiation received by this collector is $\mathrm{I}=\mathrm{I}_{0} \cdot \mathrm{S}_{\text {ef }}$.

\subsection{Cylindrical Air-Heating Solar Collector}

We suggest a new kind of solar collector - a cylindrical solar collector. The main idea is that the absorber is cylindrical and receives solar radiation from all sides. The axis of the cylinder is positioned perpendicularly to the orbital plane of the earth to ensure perpendicular incidence of sun rays on the absorber.

In our case it is an air heating solar collector, but such form of the absorber can be used for water heating as well, and even for photovoltaics. Our cylindrical air heating solar collector (Fig. 1, Fig. 2) consists of two coaxial cylinders: the inner cylinder is made of black-painted metal (galvanized $0.5 \mathrm{~mm}$ thick steel sheet coated with black mat silicon colour), and the outer one is made out of a transparent $1 \mathrm{~mm}$ thick PET material coated with UV-protective film.

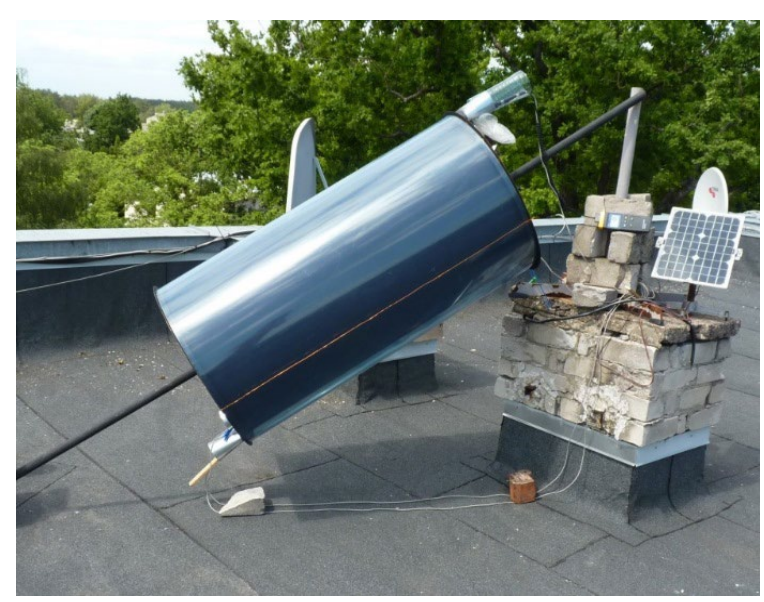

Fig. 1. Cylindrical solar collector. 
Such construction forms two spaces - the inner one inside the metallic cylinder, and the space between the metallic cylinder and the transparent one - where air can be heated. Diameter of the inner cylinder is $0.59 \mathrm{~m}$, the outer $0.67 \mathrm{~m}$, the length of both cylinders is $1.3 \mathrm{~m}$.

Both cylinders are mounted on one axis positioned at South - North direction and the Northern end is lifted at $90^{\circ}$ angle minus height of the sun at midday (pointed to the Polar star) to ensure perpendicular striking of solar beams to the collector surface all day long. Ends of the cylinders are closed with metal discs, covered with 3 $\mathrm{cm}$ thick Rockwool heat insulation from inside. There are openings in the discs for inflow of cold air and outflow of heated air. These openings are positioned so that inflow is at the bottom of the lower end of the cylinder and outflow is at the top of the upper end of the cylinder. Such positions allow convection-provided flow of air without a fan. All of these openings consist of two channels and a valve, allowing the use of heated air from the inner cylinder and from the space between the metallic cylinder and the transparent one, either together or separately.

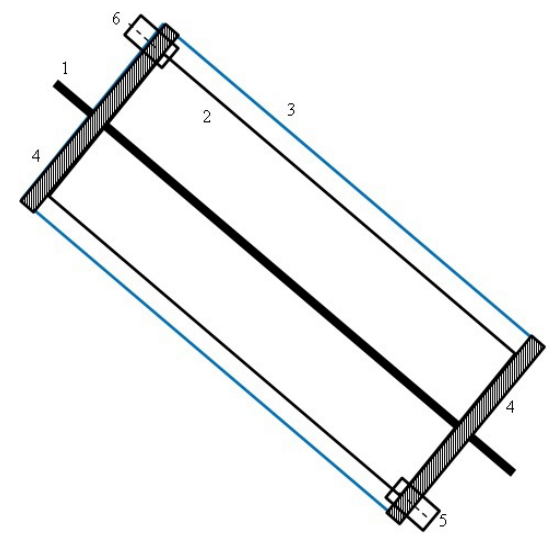

Fig. 2. Structure of cylindrical solar collector: 1 - axis, 2 - inner cylinder - absorber, 3 - outer transparent cylinder, 4 - thermoinsulation at ends, 5 - inflow opening, 6 - outflow opening.

An electrical fan was used to increase the air flow through the collector and, therefore, also its efficiency. For autonomy, the fan was powered from solar energy (photovoltaic). Such an approach can also ensure almost constant temperature of heated air due to decrease in air flow when intensity of solar radiation decreases, which in other cases can be ensured by using complicated automatics.

The temperature of inflowing and outflowing air was measured with data logger HOBO-H08-007-02 after every 2 minutes. The total air flow was measured using flowmeter Lutron YK-2001TM. Then the energy outcome from the collector $Q$ can be calculated: $Q=c \cdot m \cdot \Delta T$, where $c$ is specific heat of the air, $m$ is mass of the heated air and $\Delta T$ is the difference between inflowing and outflowing air temperatures. The mass of heated air can be obtained: $m=p \cdot V /(R \cdot T \cdot \mu)$, where $p$ is air pressure, $V$ is volume, $R$ is universal gas constant and $\mu$ is molecular weight of air. The volume is product of flow rate with cross-sectional area of the tube and time. The fan we used ensured velocity of air flow of $4 \mathrm{~m} / \mathrm{s}$ at clear sun conditions, which for air inflow and outflow channels (diameter equal to $8 \mathrm{~cm}$ ) gave air flow of $0.02 \mathrm{~m}^{3} / \mathrm{s}$ or $72 \mathrm{~m}^{3} / \mathrm{h}$. 
For the evaluation of the proportionality between energy gain from the collector and solar energy, the global solar energy was measured using ISO 1-st class Kipp\&Zonen piranometer CMP 6 (positioned horizontally). Measurements were taken automatically after every 5 minutes.

\section{RESULTS AND DISCUSSION}

\subsection{Calculated Daily Course of Power of Cylindrical Solar Collector}

The daily course of power of cylindrical solar collector was calculated using methodology explained in Section 2.1.2 and compared with that of a flat plate collector positioned at the slope corresponding to maximum power at midday. Results are shown in Fig. 3.

As it was expected, cylindrical collector received more energy in the morning and evening than a flat one, but at midday power of both collectors was equal, if effective areas were equal. Daily energy sum of the cylindrical solar collector is 1.5 times greater than that of the flat one. Of course, real surface area of this cylindrical collector is larger than that of the flat one, but for the flat collector it is necessary to insulate back-side, while the cylindrical collector does not require it. Also the space occupied by the collector can be an important factor to decide in favour of the cylindrical one.

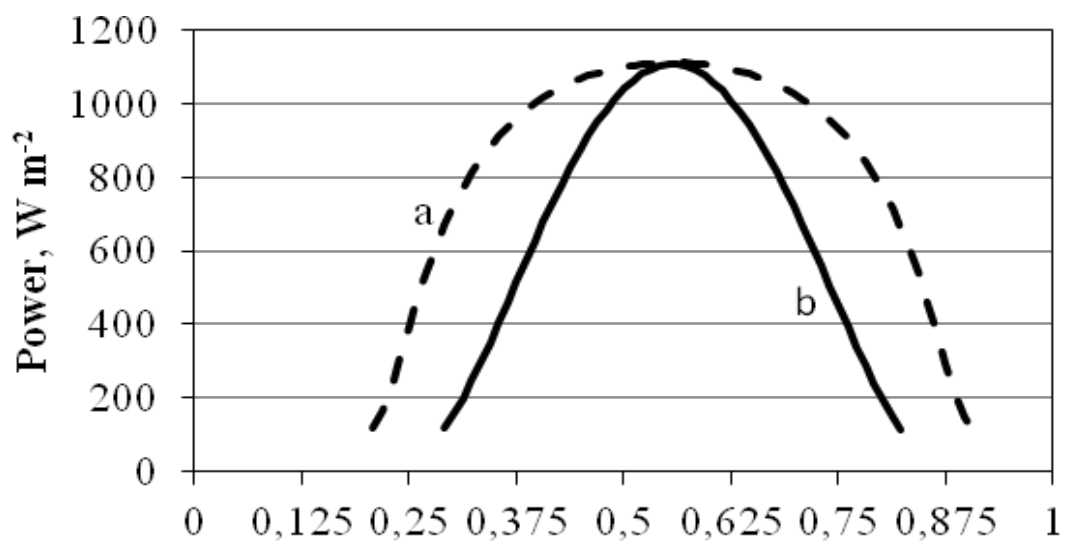

Time

Fig. 3. Daily course of power of cylindrical (a) and flat (b) solar collectors.

\subsection{Temperature of Heated Air}

Measured temperature of outflowing air from a cylindrical solar collector gives similar results as calculations. Daily course of temperature of heated air together with intensity of global solar radiation at almost clear day (3 August 2015) is shown in Fig. 4. 


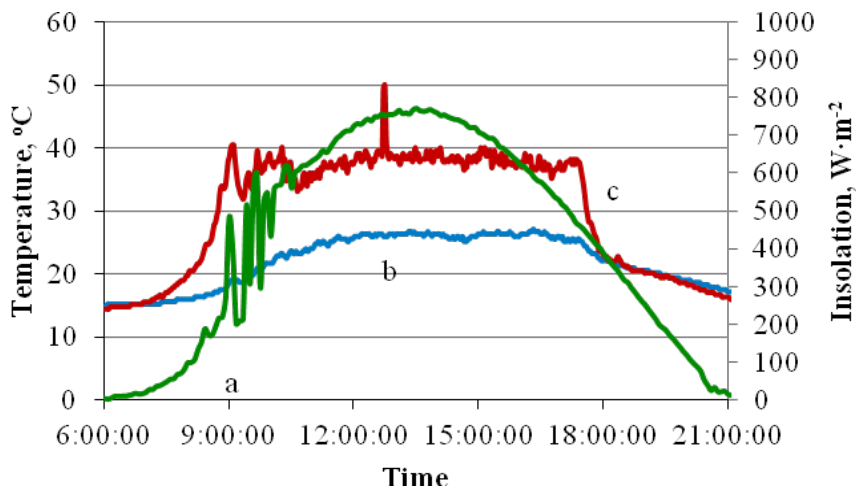

Fig. 4. Daily course of temperature of air heated with cylindrical solar collector at almost clear day (3 August 2015): a - solar radiation, $\mathrm{W} \cdot \mathrm{m}^{-2} ; \mathrm{b}$ - temperature of ambient air, ${ }^{\circ} \mathrm{C} ; \mathrm{c}-$ temperature of heated air, ${ }^{\circ} \mathrm{C}$.

As seen from Fig. 4, temperature of the heated air reached $35^{\circ} \mathrm{C}$ soon after sunrise and remained almost constant during the day. Air flow under such sunny conditions was constant and equal to $4 \mathrm{~m} / \mathrm{s}$ or $72 \mathrm{~m}^{3} / \mathrm{h}$. It resulted in daily mean power of the space between absorber and transparent coating $214 \mathrm{~W}$, and of the space inside the absorber $192 \mathrm{~W}$. In these measurements air flew through both these spaces; therefore, total daily mean power of the collector was $406 \mathrm{~W}$. Such power is sufficient for drying of agricultural production. Similar results were also obtained at a partly cloudy day (Fig. 5).

Figure 5 shows daily course of temperature of the heated air together with the intensity of solar radiation at a partly cloudy day of 9 August 2015.

In this case, the temperature of heated air is even higher than at clear day, but this can be explained with accumulating of the warm air in the collector when the solar energy powered fan does not work due to clouds. This, in turn, means that such a fan powered by solar energy can be used instead of complicated automatics for ensuring approximately constant temperature of the heated air under partly cloudy conditions.

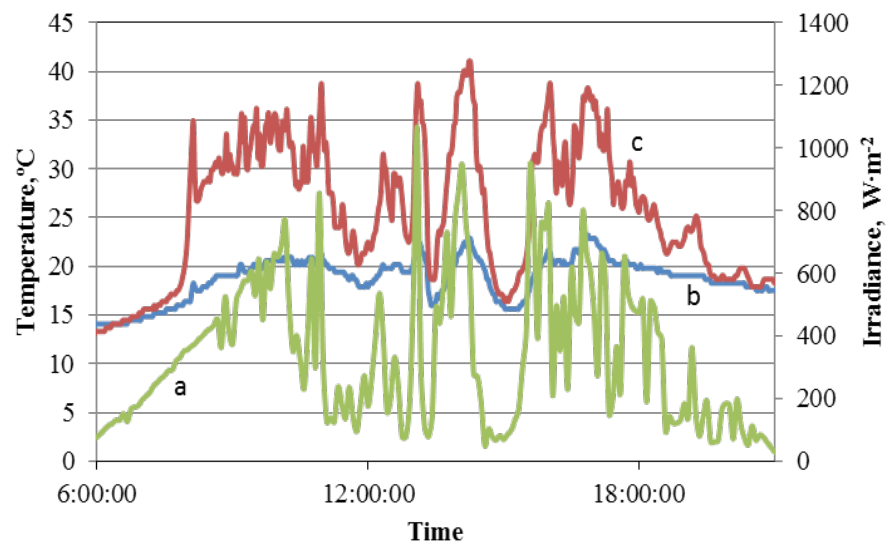

Fig. 5. Daily course of temperature of air heated with cylindrical solar collector at a partly cloudy day (9 July 2015): $\mathrm{a}$ - solar radiation, $\mathrm{W} \cdot \mathrm{m}^{-2} ; \mathrm{b}$ - temperature of ambient air, ${ }^{\circ} \mathrm{C} ; \mathrm{c}-$ temperature of heated air, ${ }^{\circ} \mathrm{C}$. 
Another interesting fact (Fig. 5) is that when clouds appear, solar energy among the clouds is higher than that of a clear day. It means that we receive not only direct radiation, but also radiation reflected from clouds, which, in general, is in the other direction than the direct one. Therefore, the cylindrical solar collector, which receives energy from all sides, has additional advantages in comparison with the flat one.

\subsection{Daily Energy Gain from Cylindrical Solar Collector}

In order to predict energy gain from a solar collector if global solar energy is known, the relevance between these two values must be studied (Pelece \& Ziemelis 2012). Figure 6 shows a plot of dependence of daily energy gain from the cylindrical solar collector on daily sum of global (the direct radiation together with the diffused one) solar energy on 3-26 July 2015.

The graph shows direct proportionality between these values. Slope of linear trendline is the coefficient of proportionality, in this case 0.48 , with coefficient of determination $\mathrm{R}^{2}=0.78$. These measurements were performed using only the space between the absorber cylinder and the transparent one (inner space of the absorber cylinder was closed from both ends). Similar results were obtained when only the inner space of the cylinder was used (space between absorber and transparent cover was closed). In this case, coefficient of proportionality was 0.52 with $\mathrm{R}^{2}=0.86$. Maximal coefficient of proportionality by using both spaces together was obtained, it was 0.63 . In this case also the scattering of data was the smallest one $-\mathrm{R}^{2}$ was 0.93 . Such value of coefficient of proportionality means approximately $12 \mathrm{MJ}$ or $3.3 \mathrm{kWh}$ of energy at medium cloudy day in August, or heater with $500 \mathrm{~W}$ power during the day. Such power is sufficient for drying of agricultural production.

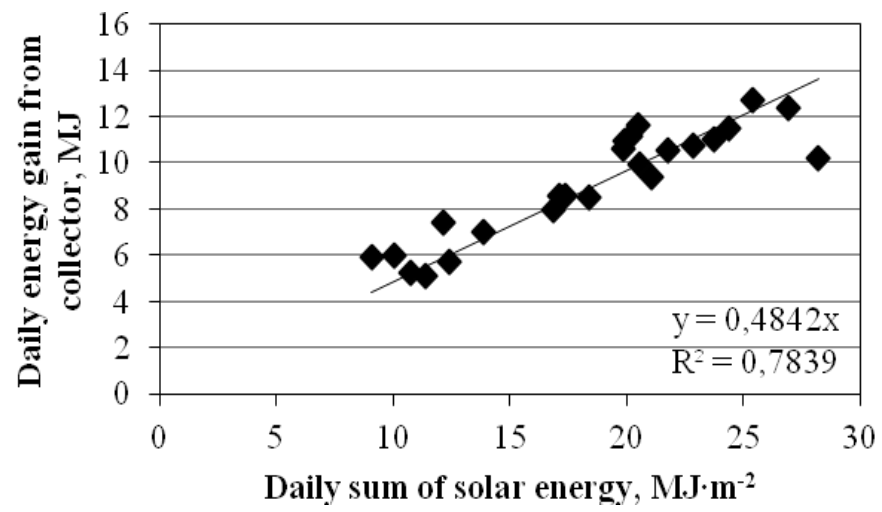

Fig. 6. Dependence of daily energy sums produced by cylindrical solar collector on those of global solar energy, 3-26 July 2015.

Large value of the coefficient of determination means that the coefficient of proportionality is only slightly dependent on solar radiation, cloudiness and other circumstances. Global solar energy depends on cloudiness, but the effectiveness of its use in a cylindrical solar collector is not affected by it. 


\section{CONCLUSIONS}

There is a new simple method for calculation of received solar energy proposed in the present research. This method is mainly based on astronomical considerations on how to describe position of the sun in the sky. This method allows calculating the direct solar energy received by surface of any shape and position under clear-sky conditions, taking into account also atmosphere mass. It may be widely used for finding the best positioning of a traditional flat-plate solar collector (or photovoltaic) as well as for developing of new shapes of solar devices.

There is a new form of solar collector developed using this method - a cylindrical solar collector. The main advantage of such a collector is the possibility to receive solar energy from all sides and during all day, even if the length of day is 17 hours. This possibility can be compared to the sun tracking collector, but the cylindrical collector does not contain moving parts. Average power output of such an airheating collector (diameter of $0.6 \mathrm{~m}$ and length of $1.3 \mathrm{~m}$ ) is $500 \mathrm{~W}$, or daily energy sum is 6 to $15 \mathrm{MJ}$ (or 1.7 to $4.2 \mathrm{kWh}$ ) in August in Latvia. Such power is sufficient for drying of agricultural production. An air-heating collector has been considered in this article, but main ideas can also be used for water-heating collectors and even for photovoltaics.

\section{REFERENCES}

1. Abdulhadi, M.. and Ghorayeb, F. (2006). A self-tractable solar collector. International Journal of Sustainable Energy, 25(2), 63-78.

2. Ahwide, F., Spena, A., and El-Kafrawy, A. (2013). Correlation for the average daily diffuse fraction with clearness index and estimation of beam solar radiation and possible sunshine hours fraction in Sabha, Ghdames and Tripoli - Libya. APCBEE Procedia, 5, 208-220.

3. Andersen, E. et al. (2015). Measurements of the angular distribution of diffuse irradiance. Energy Procedia, 70, 729-736.

4. http://ssd.jpl.nasa.gov/horizons.cgi.

5. ISO 9488:1999(E/F) 3.24.

6. Chikh, M., Mahrane, A., and Haddadi, M. (2012). Modeling the diffuse part of the global solar radiation in Algeria. Energy Procedia, 18, 1068-1075.

7. Chong, K.K., and Wong, C.W. (2009). General formula for on-axis sun-tracking system and its application in improving tracking accuracy of solar collector. Solar Energy, 83, 298-305.

8. Hobbi, A., and Siddiqui, K. (2009). Optimal design of a forced circulation solar water heating system for a residental unit in cold climate using TRNSYS. Solar Energy, 83, 700-714.

9. Young, A.T. (1994). Air mass and refraction. Applied Optics, 33, 1108-1110.

10. Kadirgan, F. (2006). Electrochemical nano-coating processes in solar energy systems. Hindawi Publishing Corporation International Journal of Photoenergy, (Article ID 84891), 1-5.

11. Kurtbas, I., and Durmus, A. (2007). A comparison of a new type conical solar collector with a flat-plate solar collector. e-Journal of New World Sciences Academy, 2 (Article Number A0028 ISSN 1306-3111). 
12. Meclouch, R.F., and Brahim, A. B. (2008). A global solar radiation model for the design of solar energy systems. Asian Journal of Scientific Research, 1(3), 231-238.

13. Mghouchi, Y. et al. (2014). New model to estimate and evaluate the solar radiation. International Journal of Sustainable Built Environment, 3(2), 225-234. Available at: http:// www.sciencedirect.com/science/article/pii/S221260901400051X.

14. Pelece, I., Vanags, M., and Migla, L. (2010). Evaluation of atmospheric lucidity and diffused radiation. Latvian Journal of Physics and Technical Sciences, 6, 40-46.

15. Pelece, I., and Ziemelis, I. (2012). Water heating effectiveness of semi-spherical solar collector. In Proceedings of International Scientific Conference "Renewable Energy and Energy Efficiency”. LLU, ISBN 978-9984-48-070-1, 185-188.

16. Siwulski, S., Nocun, M., and Gruszka, B. (2005). Glassy coating for solar energy conversion. Optica Applicata, 35(4).

17. Slama, R. B. (2009). Incidental solar radiation according to the solar collector slope Horizontal measurements conversion on an inclined panel laws. The Open Renewable Energy Journal, 2, 52-58.

18. Zagars, J., and Vilks, I. (2005). Astronomija augstskolam, Riga, Latvia: LU.

\title{
CILINDRISKA GAISA SILDĪŠSANAS SAULES KOLEKTORA TEORĒTISKIE UN EKSPERIMENTĀLIE PĒTİJUMI
}

\author{
I. Pelēce, P. Šipkovs \\ Kopsavi $1 \mathrm{kums}$
}

Saules energíija tiek izmantota ne tikai dienvidu zemēs, kur tā ir pieejama lielos daudzumos, bet arī lielākos platuma grādos, kur saules augstums un starojuma intensitāte ir daudz mazāki. No otras puses, vasarā lielākos platuma grādos ir garāka diena, nekā dienvidos, un arī saules ceḷ̌s ir garāks.

Šis darbs veltīts pētījumiem par jaunām saules kolektoru konstrukcijām, kuras spēj san,emt vairāk saules enerğijas.

Jaunu saules kolektoru formu projektēšanai un novērtēšanai ir nepieciešamas arī jaunas virsmas saṇemtās saules enerğijas aprēḳinu metodes. Metode ir aprakstīta šajā darbā.

Balstoties uz piedāvātās metodes aprēķiniem, jaunas formas saules kolektors cilindrisks kolektors - ir izstrādāts. Šis kolektors ir paredzēts gaisa sildīšanai, bet var tikt izmantots arī ūdens sildīšanai, kā arī fotoelementiem.

Cilindrisks kolektors no rīta un vakarā saņem vairāk enerǵijas nekā plakans kolektors, bet pusdienas laikā kolektoru jauda ir vienāda, ja efektīvie laukumi ir vienādi. Iegūtās enerǵijas dienas summa no cilindriska saules kolektora ir 1,5 reizes lielāka nekā no plakanajam.

19.04.2016. 